\title{
LETTER
}

\section{The renal angiopoietin/Tie2 system in lethal human sepsis}

\author{
Adnan Aslan ${ }^{1}$, Rianne M Jongman², Jill Moser ${ }^{1}$, Coen A Stegeman ${ }^{3}$, Harry van Goor ${ }^{4}$, Arjan Diepstra ${ }^{5}$, \\ Marius C van den Heuvel ${ }^{5}$, Peter Heeringa ${ }^{4}$, Grietje Molema ${ }^{4}$, Jan G Zijlstra ${ }^{1 *}$ and Matijs van Meurs ${ }^{1}$
}

Sepsis-induced multi-organ dysfunction syndrome (MODS) still has a high mortality. Improvements await a better understanding of the pathophysiological mechanisms. The angiopoietin (Ang) $1 / 2$ and Tie2 (tyrosine kinase with immunoglobulin and epidermal growth factor homology domains 2) ligand/receptor system is an important regulator of endothelial cell responses to severe insults [1]. Plasma Ang2 levels are prognostic in sepsis, but data on Ang/Tie responses in organs in humans are lacking [2-5]. We hypothesized that, in kidneys of patients who died of sepsis with acute kidney injury (AKI), the Ang/Tie signaling system is changed in such a way that microvessels become destabilized.

Patients dying with sepsis-induced MODS were included. In the family conference preceding withdrawal or withholding of therapy, permission was asked for a renal biopsy as a partial autopsy to be performed immediately after death. The family was asked to give signed consent. The unaffected part of kidneys removed for renal cell carcinoma was used as a control $(\mathrm{n}=8)$. mRNA was analyzed as described [3].

Table 1 Patient characteristics

\begin{tabular}{|c|c|c|c|c|c|c|c|c|}
\hline Patient & $\begin{array}{l}\text { Age, } \\
\text { years }\end{array}$ & Diagnosis & $\begin{array}{l}\text { LOS in } \\
\text { ICU, days }\end{array}$ & RIFLE & $\begin{array}{l}\text { RRT } \\
\text { needed? }\end{array}$ & $\begin{array}{l}\text { Time to biopsy, } \\
\text { minutes }^{\text {a }}\end{array}$ & $\begin{array}{l}\text { Number of } \\
\text { glomeruli }^{b}\end{array}$ & Predominant histologyc \\
\hline 1 & 85 & $\begin{array}{l}\text { Small bowl } \\
\text { ischemia }\end{array}$ & 3 & $\mathrm{R}$ & No & 32 & 61 & Apoptosis, flattened epithelium, vacuoles \\
\hline 2 & 62 & Pneumosepsis & 1 & I & No & 25 & 24 & Apoptosis, flattened epithelium \\
\hline 3 & 55 & Pneumosepsis & 2 & । & Yes & 30 & 40 & Little apoptosis, flattened epithelium, vacuoles \\
\hline 4 & 62 & $\begin{array}{l}\text { Necrotizing } \\
\text { fasciitis }\end{array}$ & 2 & $\mathrm{~F}$ & No & 150 & 22 & $\begin{array}{l}\text { Focally lymphoid infiltration, evident } \\
\text { vacuolization, flattened epithelium }\end{array}$ \\
\hline 5 & 57 & $\begin{array}{l}\text { Colon } \\
\text { perforation }\end{array}$ & 2 & $\mathrm{~F}$ & Yes & 31 & 15 & Dilated glomerular capillaries, vacuolization \\
\hline 6 & 83 & $\begin{array}{l}\text { Small bowel } \\
\text { ischemia }\end{array}$ & 1 & । & No & 45 & 26 & Apoptosis, vacuolization \\
\hline 7 & 78 & Pneumonia & 2 & $\mathrm{~F}$ & Yes & 25 & 19 & $\begin{array}{l}\text { Focally leukocyte infiltration, apoptosis, } \\
\text { flattened epithelium }\end{array}$ \\
\hline 8 & 79 & $\begin{array}{l}\text { Necrotizing } \\
\text { fasciitis }\end{array}$ & 6 & $\mathrm{~F}$ & No & 43 & 47 & $\begin{array}{l}\text { Apoptosis, flattened and lost epithelium, } \\
\text { vacuolization }\end{array}$ \\
\hline 9 & 77 & Pneumonia & 3 & $\mathrm{~F}$ & No & 50 & 22 & Apoptosis, flattened epithelium \\
\hline 10 & 53 & Pneumonia & 2 & $\mathrm{~F}$ & Yes & 35 & 69 & Apoptosis, flattened epithelium \\
\hline 11 & 83 & $\begin{array}{l}\text { Sinusitis, } \\
\text { meningitis }\end{array}$ & 2 & $\mathrm{~F}$ & Yes & 53 & 27 & Neutrophil infiltration (nodular), vacuolization \\
\hline
\end{tabular}

${ }^{a}$ Time between circulation arrest and renal biopsy; ${ }^{b}$ number of glomeruli found in the histology of the biopsy; ${ }^{c}$ pathologic conclusion of the histology of the biopsies (performed by MH and AD). LOS in ICU, length of stay in the intensive care unit; RIFLE, Risk, Injury, Failure, Loss, End-stage kidney injury; RRT, renal replacement therapy.

\footnotetext{
* Correspondence: j.g.zijlstra@umcg.nl

${ }^{1}$ Department of Critical Care, University Medical Center Groningen, University

of Groningen, Hanzeplein 1, Groningen 9700RB, The Netherlands

Full list of author information is available at the end of the article
} 
Histopathology revealed abnormalities without a recognizable pattern (Table 1). CD31 mRNA, a panendothelial marker, did not differ between patients and controls, suggesting equal endothelial content in the biopsies (Figure 1). Neutrophil gelatinase-associated lipocalin, a sensitive marker for renal damage, showed increased mRNA expression compatible with AKI and the histopathological findings. Ang1 mRNA in patients was decreased 10-fold, whereas Ang2 was decreased to a lesser extent. The Ang1/Ang2 ratio was decreased in sepsis. Tie 2 mRNA was reduced as was the level of expression of Krüppel-like factor (KLF)2, a shear stress sensor. A correlation was found both in patients and in controls between KLF2 and Tie2 mRNA.

Our hypothesis that the Ang/Tie system is changed in a way that microvessels become destabilized in sepsisinduced AKI is supported by our finding that Ang1, Ang1/Ang2 ratio, and Tie2 mRNA levels were decreased in immediate post-mortem renal biopsies of patients with sepsis. The consequences on protein levels are the subject of further study. We previously reported flow sensitivity of Tie2 expression [5]. Combined with the KLF2 flow sensitivity, the correlation between KLF2 and Tie2 suggests that the decrease in Tie2 in patients dying
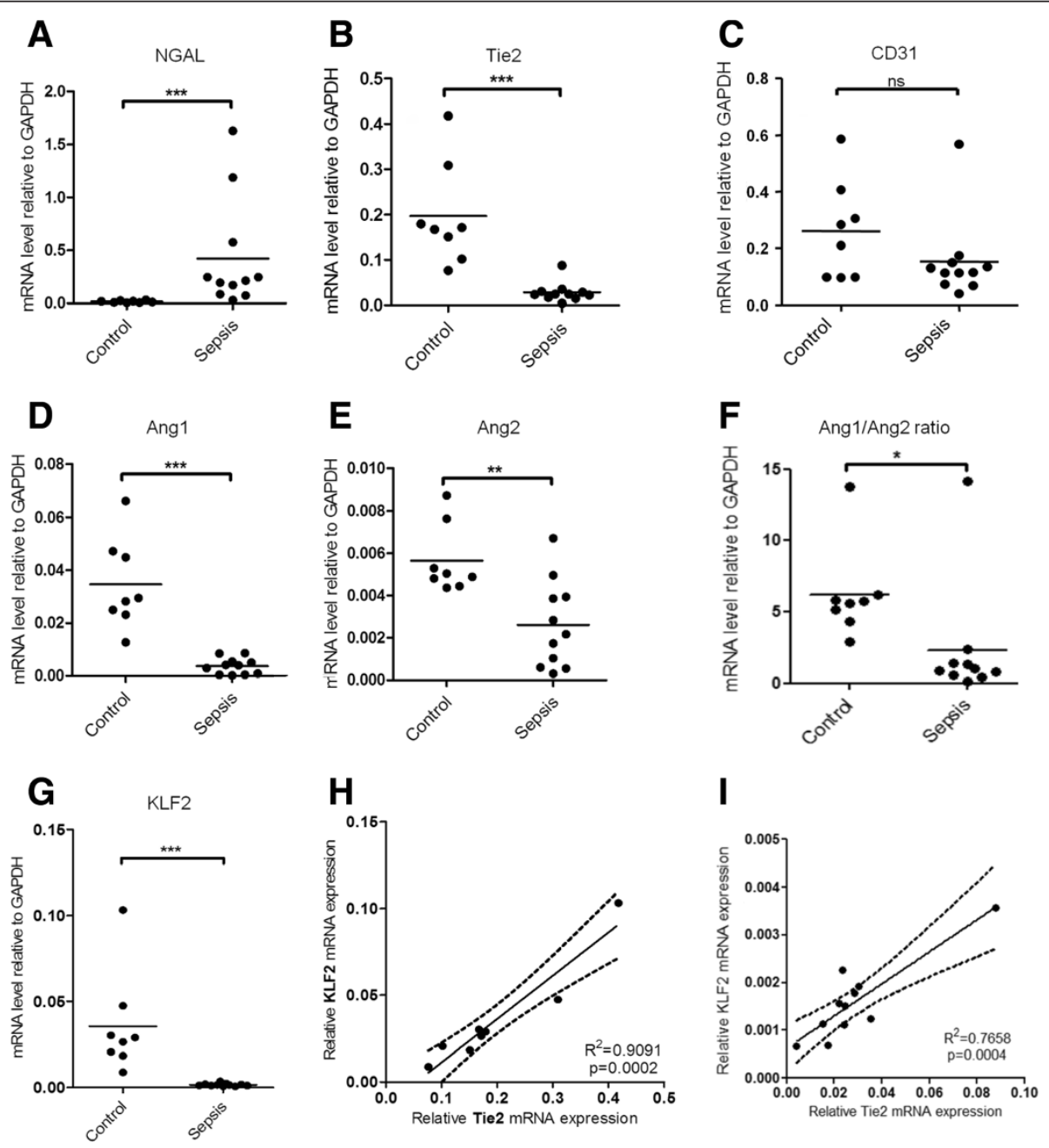

Figure 1 Kidney damage, endothelial Angiopoietin/Tie2 system, and flow responsive gene expression in renal biopsies from sepsis patients compared to healthy kidney part from patients with renal cell carcinoma. Renal neutrophil gelatinase-associated lipocalin (NGAL) (A) $(\mathrm{P}=0,0004)$, Tyrosine-protein kinase receptor TIE-2 (Tie2) (B) ( $\mathrm{P}=0,0004)$, cluster of differentiation 31 (CD31) (C) (NS), Angiopoietin 1 (Ang1) $(P=0,0003)(\mathbf{D})$, Angiopoietin 2 (Ang2) (E) $(P=0,005)$, Angiopoietin 1/Angiopoietin 2 ratio ( $F)(P=0,0467)$, Kruppel-like factor $2(K L F 2)(G)(P=0,0003)$ mRNA gene expression in renal biopsies from sepsis patients $(n=11)$ compared to healthy kidney part from patients with renal cell carcinoma $(n=8)$. Each dot represents the mean of two biopsies per patient. Tie2 gene expression levels in renal biopsies correlates with the mRNA levels of KLF2 in both control biopsies ( $R 2=0,91 ; P=0,0002)(\mathbf{H})$ as well as in kidney biopsies from sepsis patients $(R 2=0,70 ; P<0,0001)(\mathbf{I})$. Low expression of Tie2 is associated with low levels of KLF2 gene expression. Lines denote best fit, with the dashed lines representing the $95 \%$ confidence interval for best fit. ns, Not significant. ${ }^{*} P \leq 0.05 ;{ }^{*} P \leq 0.01 ;{ }^{* *} P \leq 0.001$. 
of sepsis might be due to changes in local blood flow. This mechanism would be additional to, and maybe synergistic with, other mechanisms such as inflammation and apoptosis as described in the literature and seen in the histology in our study.

Studies in organs of critically ill patients immediately after dying, especially examining gene expression status, are scarce. In biopsies taken immediately after circulation arrest, the effects of autolysis are avoided. However, patients dying of sepsis die after a long process with increasing organ damage. Instead of studying an illnessinduced change, we might be studying a shutdown process comparable to what happens at a cellular level in apoptosis. We show that immediate post-mortem samples contain high-quality RNA.

Our study is the first to show, on an organ level in humans, that the Ang/Tie2 axis is changed in AKI. The place of immediate post-mortem mRNA in the understanding of MODS should be further evaluated. It might be a new tool complementing human plasma and animal studies.

\section{Abbreviations}

AKI: Acute kidney injury; Ang: Angiopoietin; KLF: Krüppel-like factor; MODS: Multi-organ dysfunction syndrome; Tie: Tyrosine kinase with immunoglobulin and epidermal growth factor homology domains.

\section{Competing interests}

The authors declare that they have no competing interests.

\section{Acknowledgments}

The medical ethical committee considered the study as part of the regular autopsies to confirm the cause of death. The committee allowed direct postmortem renal biopsies to avoid loss of tissue integrity. The further use of anonymized tissues for research was allowed (University Medical Center Groningen, Medical Ethical Committee, chairman Willem A Kamps, registration number 2011/372). We thank Peter J Zwiers for technical assistance.

\section{Author details}

'Department of Critical Care, University Medical Center Groningen, University of Groningen, Hanzeplein 1, Groningen 9700RB, The Netherlands. ${ }^{2}$ Department of Anesthesiology, University Medical Center Groningen, University of Groningen, Hanzeplein 1, Groningen 9700RB, The Netherlands. ${ }^{3}$ Department of Nephrology, University Medical Center Groningen, University of Groningen, Hanzeplein 1, Groningen 9700RB, The Netherlands. ${ }^{4}$ Department of Pathology and Medical Biology, Medical Biology Section, University Medical Center Groningen, University of Groningen, Hanzeplein 1 , Groningen 9700RB, The Netherlands. ${ }^{5}$ Department of Pathology and Medical Biology, Pathology Section, University Medical Center Groningen, University of Groningen, Hanzeplein 1, Groningen 9700RB, The Netherlands.

\section{Published: 31 Mar 2014}

\section{References}

1. van Meurs M, Kumpers P, Ligtenberg JJ, Meertens JH, Molema G, Zijlstra JG: Bench-to-bedside review: Angiopoietin signalling in critical illness - a future target? Crit Care 2009, 13:207.

2. Kumpers P, Lukasz A, David S, Horn R, Hafer C, Faulhaber-Walter R, Fliser D, Haller $\mathrm{H}$, Kielstein JT: Excess circulating angiopoietin-2 is a strong predictor of mortality in critically ill medical patients. Crit Care 2008, 12:R147.

3. van Meurs M, Wulfert FM, Knol AJ, de Haes A, Houwertjes M, Aarts LP, Molema G: Early organ-specific endothelial activation during hemorrhagic shock and resuscitation. Shock 2008, 29:291-299.
4. van Meurs M, Kurniati NF, Wulfert FM, Asgeirsdottir SA, de Graaf IA, Satchell SC, Mathieson PW, Jongman RM, Kümpers P, Zijlstra JG, Heeringa P, Molema G: Shock-induced stress induces loss of microvascular endothelial Tie2 in the kidney which is not associated with reduced glomerular barrier function. Am J Physiol Renal Physiol 2009, 297:F272-F281.

5. Kurniati NF, Jongman RM, Vom Hagen F, Spokes KC, Moser J, Regan ER, Krenning G, Moonen JR, Harmsen MC, Struys MM, Hammes HP, Zijlstra JG, Aird WC, Heeringa P, Molema G, van Meurs M: The flow dependency of Tie2 expression in endotoxemia. Intensive Care Med 2013, 39:1262-1271.

\section{$10.1186 /$ cc13806}

Cite this article as: Aslan et al:: The renal angiopoietin/Tie2 system in lethal human sepsis. Critical Care 2014, 18:423 